\title{
Diversification on Small Farms: An Empirical Investigation of Panel Data for 2001-10
}

\section{Sadia Hussain* and Farah Said ${ }^{* *}$}

\begin{abstract}
Pakistan's agricultural sector has experienced restructuring over the last decade, from changes in land markets to the move toward nonagricultural labor markets. However, agriculture remains one of the most important sources of livelihood, accounting for 45 percent of the country's workforce. It is also a key policymaking area, but the role of small farmers in poverty reduction is still being examined. The future of small farms cannot be viewed in isolation, that is, without taking into account their synergies with nonfarm rural activities. We measure the impact of diversifying sources of livelihood on household income and consumption among small farms in rural Pakistan. Using a balanced panel of 2,058 households from the Pakistan Panel Household Survey (2001-10), we find that both consumption and income are (i) significantly higher for households that have diversified their sources of income and (ii) diversified households also plant greater varieties of crops. These results suggest that nonagricultural activities tend to complement agricultural activities with a view to improving welfare in a rural economy.
\end{abstract}

Keywords: Agriculture, income, diversification, Pakistan.

JEL classification: E2, O1, Q1.

\section{Introduction}

Across countries and over time, economic development is almost always accompanied by a decline in the agriculture-to-GDP ratio. Rural areas in many developing countries have undergone a structural transformation as agricultural households moved toward nonfarm activities. Pakistan is no exception to these trends. The share of agriculture in GDP declined from 26 to 22 percent between 2001 and 2010. However, the sector is far from becoming redundant. Agricultural activities account for 45

\footnotetext{
* Teaching and Research Fellow, Centre for Research in Economics and Business (CREB), Lahore School of Economics, Pakistan.

*** Assistant Professor and Research Fellow, CREB, Lahore School of Economics, Pakistan.
} 
percent of the workforce through direct employment. ${ }^{1}$ The benefits are amplified if we consider the indirect employment opportunities associated with cultivation, including on-farm and off-farm labor. Recent studies have emphasized the role of nonagricultural activities in sustaining the agricultural economy. That is, nonagricultural activities should be viewed as complements to, rather than substitutes for, agricultural production (van der Ploeg, 2014).

This study draws on a panel dataset collected by the Pakistan Institute of Development Economics in collaboration with the World Bank, covering households in 16 districts of Pakistan between 2001 and 2010. On average, 15 percent of the households surveyed relied on one source of income. As the dataset shows, the average consumption expenditure of a district corresponds to the average proportion of households that 'specialize' in one income source.

Figure 1 maps those districts that lie above or below the average proportion of specialized households (as mentioned above, 15 percent of the surveyed households were 'specialized' in 2001) and Figure 2 shows the quintiles of average consumption in 2010. Note that the 'specialized' districts in panel A correspond to lower average annual consumption in 2010. Conversely, this points to the possible benefits of diversifying livelihoods in a rural economy, which is what we intend to test for empirically.

In this paper, we explore structural changes at a micro level, using panel data from the Pakistan Panel Household Survey (PPHS), which covers 2,058 households across Pakistan over a ten-year period. We find that households with diversified sources of income in 2001 had statistically higher annual consumption and income in 2010. On the other hand, both consumption expenditure and income decreased for households that focused consistently on one source of income over 2001-10. The evidence also suggests complementarities in diversification: agricultural households that have diversified their sources of livelihood are also more likely to diversify the types of crops they cultivate during the year.

Despite the large body of literature on developing countries, there is a dearth of longitudinal studies on Pakistan. Kurosaki (2003) presents evidence of agricultural transformation at the district level: although aggregate land productivity in western Punjab remained unchanged during

\footnotetext{
${ }^{1}$ Based on data available from Agriculture Census Report 2010 at http://www.pbs.gov.pk
} 
1903-92, cropping patterns showed a shift in land acreage toward more productive districts. This reallocation of cultivated land from low-valueadded to cash crops explains the area's rapid agricultural growth.

Figure 1: Proportion of households that 'specialize' in one source of income

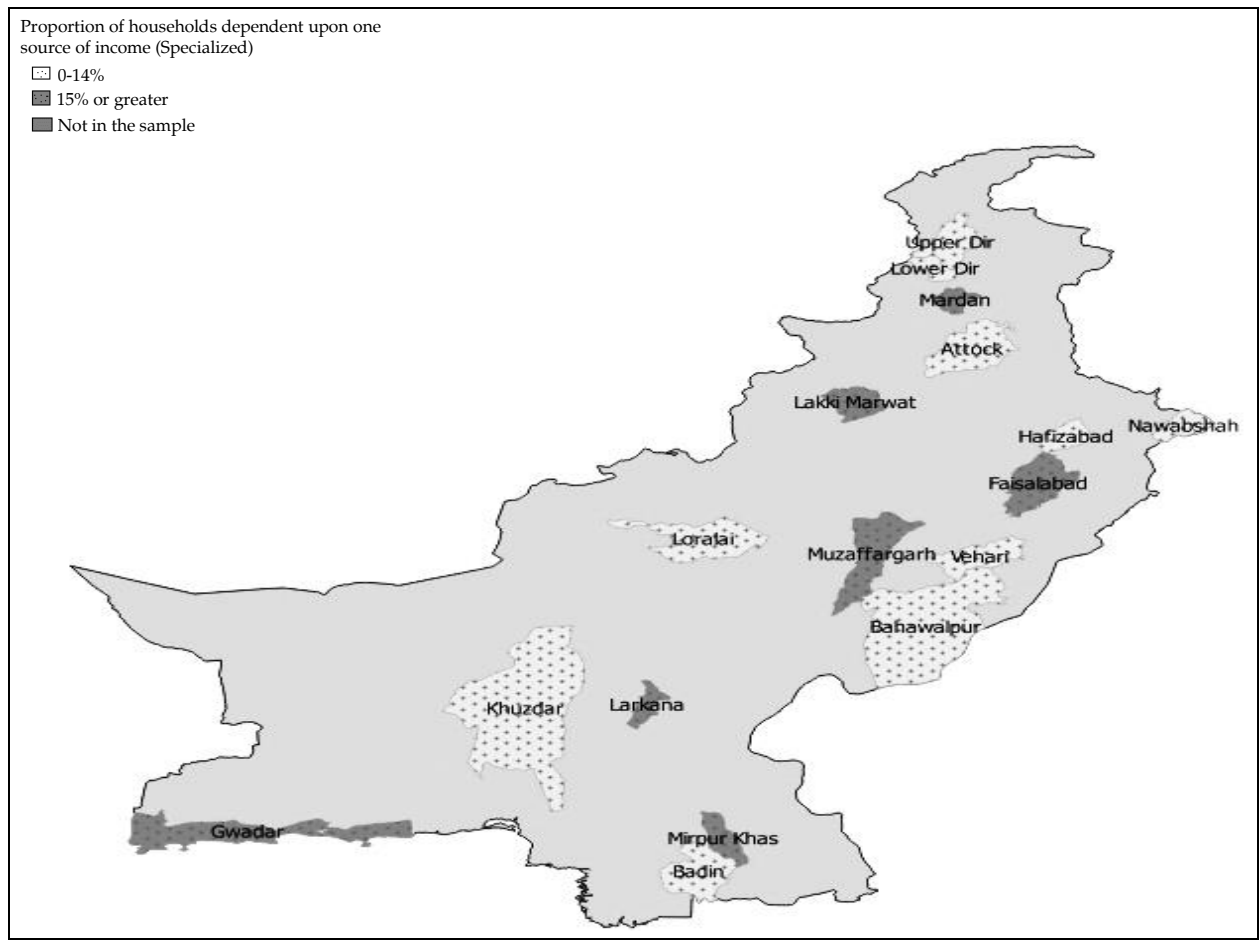

Note: Districts are grouped into two categories: above the sample district average (15 percent) and below.

Source: Based on authors' calculations, using data from the PPHS 2010.

Rapid specialization in crop production seemed to be the norm in the early 1990s. Until recently, most studies on agricultural growth focused on scale enlargement, intensification and specialization. Conversely, such scalecentric policies were associated with persistent rural poverty as well as increased regional disparities (Knickel, 1990). Furthermore, the removal of agricultural subsidies after trade liberalization changed the country's economic landscape (Bryceson, 1999). This explains why it is necessary to revisit the paradigm by exploring the livelihood strategies of rural households through the lens of diversification. 
Figure 2: District average of annual real consumption expenditure, 2010

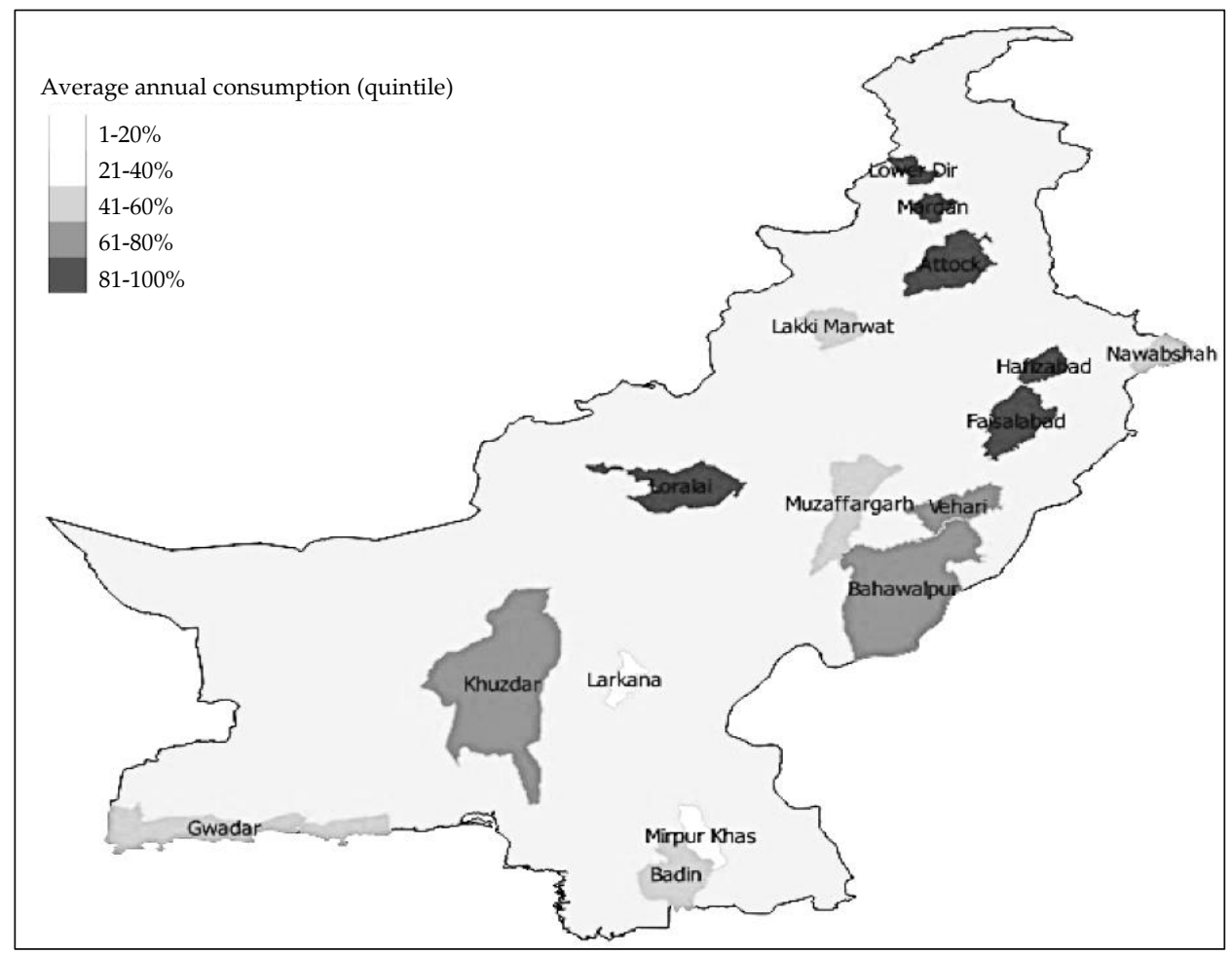

Source: Based on authors' calculations, using data from the PPHS 2010.

Rural development is not nested in agricultural activities alone. Rather, it needs to be promoted through the synergies between agricultural and nonagricultural activities. Previous studies have explored why households move toward nonfarm activities. On one hand, the burgeoning nonagricultural sector offers higher rates of return, thus 'pulling' in productive household resources, particularly capital and labor. On the other hand, the volatility of returns arising from negative production shocks, missing insurance markets and credit constraints 'push' households away from agricultural activities. Barrett et al. (2000) find that the livelihood strategies adopted by rural households depend on household characteristics, geography, climate and market institutions. The diversification of livelihood strategies follows a distinct pattern among wealthier households, which diversify into capital-intensive and more remunerative activities, while poor households are restricted to activities with low barriers to entry. 
Farm wage employment emerges as a popular choice because it provides a safety net to households that are below the poverty line and are vulnerable to negative shocks. Richer households have both the capacity and incentive to move into more profit-generating activities through greater investment. Furthermore, they have the necessary human capital and marketable skills to develop nonfarm alternatives. This phenomenon is referred to as the "meso-paradox". Reardon, Berdegué and Escobar (2001) use data from 11 rural household income studies and find an increase in the multi-activity rate, moving from the poorest to the richest income quartiles in Latin America. Interestingly, some forms of diversification are evident irrespective of the level of income.

The role of diversification in livelihoods to promote rural development has been contested by many researchers. Diversification can weaken agricultural productivity when alternative activities compete for productive resources. While diversification serves as a risk management tool, it may also keep households from taking a higher risk-return approach. Finally, the gains from specialization may be lost through diversification (Berkvens, 1997; Collier \& Gunning, 1997). On the other hand, proponents of diversification correlate welfare with involvement in multiple activities. In this sense, diversification can be used as a risk coping and accumulation strategy.

Recent findings from agro-based economies show that many have transitioned from relying heavily on agriculture to nonagricultural activities. Furthermore, these income-diversifying strategies vary between African and non-African economies. While 51 percent of African households tend to specialize, ${ }^{2}$ diversification is more common among non-African economies ${ }^{3}$ (Davis, Di Giuseppe \& Zezza, 2017). Other studies on rural livelihood strategies support this argument, finding that nonfarm earnings are significantly higher than agricultural wage or self-employment earnings. Around three quarters of the rural households in Africa rely on off-farm activities for consumption smoothing (Bryceson, 1999).

Other studies suggest that the livelihood strategies of rural households are more complex, emanating from the linkages between farm and nonfarm activities - the two are linked through channels of investment,

\footnotetext{
${ }^{2}$ Specialization is concentrated in nonagricultural wage employment and self-employment. 3 Only 21 percent of households in non-African economies specialize. These households diversify into farm-related activities at lower levels of development.
} 
production and consumption. An increase in agricultural production leads to higher levels of household income, resulting in an increase in demand for nonagricultural outputs. In one sense, the linkages between on-farm and offfarm activities are complementary and set the stage for diversification (van der Ploeg, 2014; Wiggins, Kirsten \& Llambí, 2010; Reardon et al., 2001).

Based on the literature, this study explores whether similar complementarities exist between agricultural and nonagricultural activities among rural households in Pakistan. It also gauges the impact of diversification on household welfare, as measured by household income and consumption. Section 2 outlines the research questions and empirical strategy followed. Section 3 describes the data and identifies some interesting patterns that emerge from this. Section 4 presents the results of our empirical analysis. Section 5 concludes the study and provides some policy implications.

\section{Empirical Strategy}

In examining the impact of rural dynamics on household welfare over the period 2001-10, we see a substantial movement between occupations and ask what has motivated this. Indeed, traditional economic theory would suggest that specialization leads to increased returns and so, households that wish to maximize their income should concentrate on their most lucrative source of income. However, diversification can help stabilize income and allow consumption smoothing, which may be more important to cash-constrained households. What, then, is the impact of diversification - relative to specialization - on household spending?

Looking at two conventional measures of welfare and poverty (for which data is available), consumption and income, we ask if diversified households have had better welfare indicators than specialized households over the last decade. Using panel data enables us to follow the same households over time and control for other time-varying factors.

We test for the effect of diversification on real consumption and income values in 2010 by running the following regression:

$y_{h, 2010}=\beta_{0}+\delta_{1}$ Diversified $_{h, 2001}+\delta_{2}$ Diversified $_{h, 2010}+$ $\delta_{3}$ Diversified $_{h, 2001} *$ Diversified $_{h, 2010}+\beta_{1} X_{h, 2001}+\varepsilon_{h, t}$

where $y_{h, 2010}$ is the real annual consumption or income for household $h$. Diversified is a binary variable equal to 1 if the household has more than one 
source of livelihood. Equation (1) measures the effect of diversification in each period and the effect of consistently diversifying as compared to those households that were specialized in both 2001 and 2010. The vector $X_{h, 2001}$ includes baseline (2001) characteristics such as the number of literate members of the household or, if the household head is literate, his or her age, the dependency ratio and household assets as a proxy for household wealth. All consumption and income values have been deflated to 2001 values.

All the regressions and results given in Section 4 are robust to the inclusion of district-level effects. All errors are clustered at the household level and robust standard errors reported.

\section{Data}

The PPHS provides a longitudinal database of key social and poverty indicators. The first round of the survey, conducted in 2001, covers rural households across 16 districts in Pakistan. For security reasons, districts in Khyber Pakhtunkhwa and Balochistan were not surveyed in the second round in 2004. However, the third round, carried out in 2010, includes all the households surveyed originally in 2001 as well as urban households in the 16 districts. ${ }^{4}$ Independent researchers have established that sample attrition over the three rounds is nonrandom (Nayab \& Arif, 2014). We use a balanced panel of 2,058 rural households surveyed in both 2001 and 2010. Since the 2010 round was conducted during a period of high inflation, we have used inflation-adjusted values for the nominal income and consumption variables employed. 5

\subsection{Sample Description}

Table 1 describes key characteristics of the sampled households. On average, 80 percent of the total sample can read and write. A typical household earned slightly more than PKR400,000 in 2001 and has an annual consumption of approximately PKR128,000. The inflation-adjusted values of both income and consumption were lower in 2010. Interestingly, the sampled households appear to accumulate significant savings over one year, arguably by investing in durable assets.

\footnotetext{
4 The PPHS is public data, shared free of cost. The questionnaires, data and sampling strategy is available at: http:/ /www.pidelms.com/pphs /

5 Available from: http://data.worldbank.org/. All nominal values were deflated using 2001 as the base year.
} 
Table 1: Sample statistics for a balanced panel consisting of 2,058 households

\begin{tabular}{lccl}
\hline Variable & $\mathbf{2 0 0 1}$ & $\mathbf{2 0 1 0}$ & p-value \\
\hline Age of household head (years) & 47 & 51 & $0.000^{* * *}$ \\
Income (2001 values, PKR) & 425,813 & 382,305 & 0.851 \\
Consumption (2001 values, PKR) & 128,513 & 108,222 & $0.000^{* * *}$ \\
Family size & 8 & 7 & 0.486 \\
Dependency ratio & 0.9830 & 0.9504 & 0.192 \\
Literacy to family size ratio & 0.4130 & 0.4640 & $0.000^{* * *}$ \\
Landownership (\%) & 56 & 60 & $0.009^{* * *}$ \\
$\quad$ Small: 3 acres or less (\%) & 25 & 20 & 0.188 \\
$\quad 19$ & 16 & $0.056^{* *}$ \\
Medium: 3 to 10 acres (\%) & 12 & 24 & $0.005^{* * *}$ \\
Large: more than 10 acres (\%) & & & \\
Cultivation (\%) & 56 & 53 & $0.041^{* *}$ \\
Livestock ownership (\%) & 70 & 74 & $0.039^{* *}$ \\
Wage employment (\%) & 67 & 88 & $0.109^{* *}$ \\
$\quad$ Nonagricultural enterprise (\%) & 20 & 10 & $0.000^{* * *}$ \\
Reported experiencing production & 55 & 84 & $0.000^{* * *}$ \\
shocks (\%) & & & \\
Type of crops cultivated in a year & 4 & 3 & $0.000^{* * *}$ \\
\hline
\end{tabular}

Note: ${ }^{* * *} \mathrm{p}<0.01,{ }^{* *} \mathrm{p}<0.05,{ }^{*} \mathrm{p}<0.1$.

Source: Authors' calculations based on data from the PPHS 2010.

More than half the rural sample consists of landowners; this proportion increases over the 10-year study period, but only a small, static minority of landowners have more than 10 acres of land. Correspondingly, more than half the respondents identify themselves as cultivators. However, wage employment remains the dominant occupation: the share of households that include a wage-earning member has risen significantly from 67 to 88 percent over the 10-year period. The shift toward a fixed income stream is understandable, given the economic situation following the 2007/08 global depression. Not surprisingly, the share of respondents who reported having experienced an income shock has also increased substantially from 55 to 84 percent. Here, another factor to consider is the impact of the heavy floods that occurred in 2010.

\subsection{Stylized Facts}

Table 2 shows the proportion of households considered 'stagnant' (relying on the same sources of livelihood over the study period) - 20 percent 
of the total sample continued the same occupation during this time. Of this proportion, over 85 percent had more than one source of income. The average household had at least three different sources of income. Tables A1 and A2 in the Appendix show that most households relied on 'livestock, cultivation and land ownership' or 'cultivation, wage employment, livestock and land ownership'.

Table 2: Sources of livelihood: Households relying on the same sources of income

\begin{tabular}{lccc}
\hline $\begin{array}{c}\text { Number of income } \\
\text { sources }\end{array}$ & $\begin{array}{c}\text { Number of } \\
\text { households }\end{array}$ & $\begin{array}{c}\text { \% of households } \\
\text { in this category }\end{array}$ & As \% of sample \\
\hline One & 57 & 14 & 3 \\
Two & 83 & 20 & 4 \\
Three & 156 & 37 & 8 \\
Four & 116 & 28 & 6 \\
Five & 8 & 2 & 0 \\
Total & 420 & 100 & 20 \\
\hline
\end{tabular}

Source: Authors' calculations based on data from the PPHS 2010.

Table 3 presents the same categories as above, but for those households that shifted between occupations, moving from one source of income to another. The total number of such households is small. However, of the 12 percent that shifted from one source(s) of income to another, the dominant category includes households with three or more different sources of income. Diversification, in terms of income source, seems to be the norm.

Table 3: Sources of livelihood: Households switching to different, but the same number of, sources of income

\begin{tabular}{lccc}
\hline $\begin{array}{c}\text { Number of income } \\
\text { sources }\end{array}$ & $\begin{array}{c}\text { Number of } \\
\text { households }\end{array}$ & $\begin{array}{c}\text { \% of households } \\
\text { in this category }\end{array}$ & As \% of sample \\
\hline One & 36 & 14 & 2 \\
Two & 76 & 30 & 4 \\
Three & 105 & 42 & 5 \\
Four & 32 & 13 & 2 \\
Total & 250 & 100 & 12 \\
\hline
\end{tabular}

Source: Authors' calculations based on data from the PPHS 2010.

Next, we look at the proportion of households that moved from a single source of income to multiple sources. Almost a third of the sample (30 percent) diversified their income sources (Table 4) and 31 percent of these households moved from a single income source to multiple sources. Table 
A3 in the Appendix shows that wage employment was the most common additional source of income.

\section{Table 4: Sources of livelihood: Households moving toward diversification}

\begin{tabular}{lccc}
\hline $\begin{array}{c}\text { Number of income } \\
\text { sources }\end{array}$ & $\begin{array}{c}\text { Number of } \\
\text { households }\end{array}$ & $\begin{array}{c}\text { \% of households } \\
\text { in this category }\end{array}$ & As \% of sample \\
\hline One to two & 117 & 19 & 6 \\
One to three & 76 & 12 & 4 \\
One to four & 0 & 0 & 0 \\
One to five & 2 & 0 & 0 \\
Two to three & 115 & 19 & 6 \\
Two to four & 91 & 15 & 4 \\
Two to five & 6 & 1 & 0 \\
Three to four & 149 & 24 & 7 \\
Three to five & 10 & 2 & 0 \\
Four to five & 21 & 3 & 1 \\
Total & 611 & 100 & 30 \\
\hline
\end{tabular}

Source: Authors' calculations based on data from the PPHS 2010.

Finally, we look at the proportion of households that moved from a diversified position to a more specialized one (Table 5). Again, about a third of the sample shifted to fewer sources of livelihood, 36 percent of which moved to a single source of income. As before, wage employment emerges as the preferred choice of occupation (see Table A4 in the Appendix).

Table 5: Sources of livelihood: Households moving toward specialization

\begin{tabular}{lccc}
\hline $\begin{array}{c}\text { Number of income } \\
\text { sources }\end{array}$ & $\begin{array}{c}\text { Number of } \\
\text { households }\end{array}$ & $\begin{array}{c}\text { \% of households } \\
\text { in this category }\end{array}$ & As \% of sample \\
\hline Two to one & 86 & 15 & 4 \\
Three to one & 85 & 15 & 4 \\
Four to one & 29 & 5 & 1 \\
Five to one & 4 & 1 & 0 \\
Four to two & 61 & 11 & 3 \\
Three to two & 170 & 29 & 8 \\
Four to three & 118 & 20 & 6 \\
Five to four & 25 & 4 & 1 \\
Total & 580 & 100 & 28 \\
\hline
\end{tabular}

Source: Authors' calculations based on data from the PPHS 2010. 
Some interesting insights emerge from this description of the sample. The first is that a significant proportion of households diversified their income sources. Traditional economic theory tends to predict such behavior in times of greater economic uncertainty. One could argue that, in the aftermath of a global financial crisis and natural disaster, there was greater economic uncertainty in 2010 than in 2001. However, an equally large proportion of households also moved toward a more specialized position.

The second point worth noting is that wage employment, which offers a relatively fixed and steady stream of income, seems to be the occupation of choice among both kinds of households. Thus, diversifying households diversify into wage employment and specializing households move away from other occupations, but often toward wage employment. To investigate if these decisions were motivated by economic concerns, we look at the impact of diversification on the income and consumption of the households in our panel.

\section{Results}

The main determinants of household welfare - total annual income and total annual consumption - are adjusted for inflation. As discussed in Section 3, our main variables of interest relate to diversification in terms of sources of income. We measure the impact of consistent diversification by households i.e. diversified in both 2001 and 2010 on income and consumption in 2010. Likewise, we gauge whether relying on one source of income in 2001 affected income and consumption in 2010. First, we identify the impact of diversification by looking at the affect of being diversified in either 2001 or 2010. Next, we explore whether this affect is coming from consistent diversification. In all the regressions, we control for baseline household characteristics (literate members of the household, dependency ratio, value of household assets and the age of the household head).

Table 6 presents the results of the regression analysis. The qualitative results are similar for both welfare measures - income and consumption. Households that were either diversified in 2001 or 2010 have higher consumption levels and substantially higher incomes than the baseline group that relied on specialized sources over the decade (columns 1 and 2). Note that households with higher levels of income and consumption in the base year (2001) did not experience an increase in income and consumption thereafter. 
Interestingly, we find the impact of diversification in a single time period disappears once the effect of consistent diversification is included. Diversified households, those that continued reliance on multiple sources of income, were better off. The results appeal to economic intuition since diversification enables households to increase investment in multiple activities over time.

\section{Table 6: Impact of diversification on real annual income and consumption}

\begin{tabular}{|c|c|c|c|c|}
\hline Dependent variable & $\begin{array}{c}(1) \\
\text { Annual } \\
\text { consumption } \\
\text { in } 2010\end{array}$ & $\begin{array}{c}(2) \\
\text { Annual } \\
\text { income in } \\
2010\end{array}$ & $\begin{array}{c}\text { (3) } \\
\text { Annual } \\
\text { consumption } \\
\text { in } 2010\end{array}$ & $\begin{array}{c}(4) \\
\text { Annual } \\
\text { income in } \\
2010\end{array}$ \\
\hline $\begin{array}{l}\text { Consumption } \\
\text { expenditure in } 2001\end{array}$ & $\begin{array}{l}0.0674^{*} \\
(0.0403)\end{array}$ & & $\begin{array}{l}0.0677^{*} \\
(0.0403)\end{array}$ & \\
\hline Income in 2001 & & $\begin{array}{l}-0.000613 \\
(0.000853)\end{array}$ & & $\begin{array}{l}-0.000672 \\
(0.000847)\end{array}$ \\
\hline Diversified in 2001 & $\begin{array}{c}27,264 \\
(16,744)\end{array}$ & $\begin{array}{c}308,887^{* * *} \\
(101,969)\end{array}$ & $\begin{array}{l}-10,884 \\
(31,473)\end{array}$ & $\begin{array}{c}-63,220 \\
(118,558)\end{array}$ \\
\hline Diversified in 2010 & $\begin{array}{l}45,899 * * \\
(22,200)\end{array}$ & $\begin{array}{c}524,806^{* * *} \\
(151,614)\end{array}$ & $\begin{array}{c}5,948 \\
(20,672)\end{array}$ & $\begin{array}{l}134,995 \\
(90,432)\end{array}$ \\
\hline $\begin{array}{l}\text { Diversified in } 2001 \text { and } \\
2010\end{array}$ & & & $\begin{array}{c}51,670 \\
(36,700)\end{array}$ & $\begin{array}{l}504,097^{* *} \\
(228,925)\end{array}$ \\
\hline $\begin{array}{l}\text { Literate household } \\
\text { members in } 2001\end{array}$ & $\begin{array}{c}23,715^{* * *} \\
(4,575)\end{array}$ & $\begin{array}{l}156,489^{* *} \\
(67,926)\end{array}$ & $\begin{array}{c}23,645^{* * *} \\
(4,578)\end{array}$ & $\begin{array}{c}155,875^{* *} \\
(67,759)\end{array}$ \\
\hline $\begin{array}{l}\text { Age of household head } \\
\text { in } 2001\end{array}$ & $\begin{array}{c}495.3 \\
(602.0)\end{array}$ & $\begin{array}{c}14,646 \\
(25,293)\end{array}$ & $\begin{array}{c}491.3 \\
(602.0)\end{array}$ & $\begin{array}{c}14608 \\
(25,286)\end{array}$ \\
\hline $\begin{array}{l}\text { Dependency ratio in } \\
2001\end{array}$ & $\begin{array}{l}-12,078 \\
(8,928)\end{array}$ & $\begin{array}{l}212,687^{* *} \\
(100,793)\end{array}$ & $\begin{array}{l}-12,321 \\
(8,941)\end{array}$ & $\begin{array}{l}210,314^{* *} \\
(100,354)\end{array}$ \\
\hline $\begin{array}{l}\text { Worth of household } \\
\text { assets (PKR) }\end{array}$ & $\begin{array}{c}0.000103 \\
(0.000111)\end{array}$ & $\begin{array}{l}-0.000357 \\
(0.000308)\end{array}$ & $\begin{array}{c}0.000108 \\
(0.000112)\end{array}$ & $\begin{array}{l}-0.000299 \\
(0.000287)\end{array}$ \\
\hline Constant & $\begin{array}{c}48,909 \\
(36,834)\end{array}$ & $\begin{array}{l}-1.607 \mathrm{e}+06 \\
(1.333 \mathrm{e}+06)\end{array}$ & $\begin{array}{l}77,447^{* *} \\
(37,050)\end{array}$ & $\begin{array}{l}-1.329 e+06 \\
(1.225 e+06)\end{array}$ \\
\hline Observations & 1,603 & 1,603 & 1,603 & 1,603 \\
\hline R-squared & 0.035 & 0.005 & 0.036 & 0.005 \\
\hline
\end{tabular}

Note: Income and consumption are inflation-indexed and presented in 2001 (PKR) values. Robust standard errors given in parentheses; errors are clustered at the household level. Dependent variable is measured in terms of inflation-adjusted PKR.

*** $\mathrm{p}<0.01,{ }^{* *} \mathrm{p}<0.05, * \mathrm{p}<0.1$.

Source: Authors' calculations based on data from the PPHS 2010. 
Next, we gauge whether diversification had an impact on household development in 2010. While baseline values matter (the baseline number of literate household members or the types of crops cultivated in 2001 are associated with higher literacy and cultivation in 2010), the effect of diversification is almost as large. ${ }^{6}$ For instance, in Table 7, the effect of livelihood diversification in 2001 increases the types of crops cultivated in 2010 twofold, relative to the baseline value of the type of crops cultivated in 2001. While the types of crops cultivated falls, on average, between 2001 and 2010 (see Table 1), the diversified sample shows an increase in the types of crops being cultivated. This signals to potential complementarities in diversification, such that diversification in occupation possibly encourages diversification in cultivation.

Table 7: Impact of diversification on the type of crops cultivated in 2010

\begin{tabular}{lc}
\hline \multicolumn{1}{c}{ Dependent variable } & Types of crops cultivated in 2010 \\
\hline Types of crops cultivated in 2001 & $0.248^{* * *}$ \\
& $(0.0252)$ \\
Diversified in 2001 & $0.495^{* * *}$ \\
Literacy to family size ratio in 2001 & $(0.184)$ \\
& $0.774^{* * *}$ \\
Age of household head in 2001 & $(0.247)$ \\
& $0.0116^{* * *}$ \\
Dependency ratio in 2001 & $(0.00378)$ \\
Worth of household assets (PKR) & $0.139^{* *}$ \\
Constant & $(0.0694)$ \\
& $1.43 \mathrm{e}-10$ \\
Observations & $(7.46 \mathrm{e}-10)$ \\
R-squared & $0.464^{*}$ \\
\hline
\end{tabular}

Note: Robust standard errors given in parentheses; errors are clustered at the household level.

${ }^{* * *} \mathrm{p}<0.01,{ }^{* *} \mathrm{p}<0.05,{ }^{*} \mathrm{p}<0.1$.

Source: Authors' calculations based on data from the PPHS 2010.

${ }^{6}$ Results available on request. 


\section{Conclusion}

Like many other developing countries, Pakistan has undergone a structural change that has shifted its mainly agrarian economy to one that relies increasingly on the services and nonfarm sectors. At the micro level, this has culminated in agrarian and rural households moving away from agriculture-based livelihoods altogether. However, many households still cope with the greater demands on their resources by drawing on multiple sources of livelihood. Our results support the argument that nonfarm activities can complement and help sustain the rural economy.

Using a 10-year panel dataset comprising 2,058 rural households, we investigate the effect of 'diversification' on household welfare, as measured by income and consumption expenditure. We find that only 15 percent of the sampled households relied on one source of livelihood. Those with diversified sources of income in 2001 and 2010 had significantly higher consumption levels in the latter period. This implies households that specialized consistently in one occupation were significantly worse off.

These results are in line with studies that emphasize the importance of synergies between agricultural and nonagricultural activities in developing countries (see Reardon et al., 2001; van der Ploeg, 2014). Moreover, the stylized facts we present for this sample point to a preference for wage employment as another source of livelihood, given that a steady stream of income allows consumption smoothing and may improve welfare. In addition, diversifying sources of livelihood tends to promote diversification in the type of crops cultivated by such households.

These findings provide important insight into rural dynamics, particularly with greater policy focus on inclusive growth. Improving rural welfare does not necessarily entail reallocating resources away from agriculture. Rather, policymakers take advantage of the complementarities between rural activities. Public investment that promotes complementary nonfarm labor in services and manufacturing could help improve overall household welfare in rural economies. 


\section{References}

Barrett, C., Bezuneh, M., Clay, D., \& Reardon, T. (2000). Heterogeneous constraints, incentives and income diversification strategies in rural Africa. Unpublished manuscript.

Berkvens, R. J. (1997). Backing two horses: Interaction of agricultural and nonagricultural household activities in a Zimbabwean communal area (Working Paper No. 24). Leiden: African Studies Center.

Bryceson, D. F. (1999). African rural labor, income diversification and livelihood approaches: A long-term development perspective. Review of African Political Economy, 26(80), 171-189.

Collier, P., \& Gunning, J. W. (1997). Explaining African economic performance (Working Paper No. 1997-2.1). Oxford: Center for the Study of African Economies.

Davis, B., Di Giuseppe, S., \& Zezza, A. (2017). Are African households (not) leaving agriculture? Patterns of households' income sources in rural sub-Saharan Africa. Food Policy, 67, 153-174.

Knickel, K. (1990). Agricultural structural change: Impact on the rural environment. Journal of Rural Studies, 6(4), 383-393.

Kurosaki, T. (2003). Specialization and diversification in agricultural transformation: The case of West Punjab, 1903-92. American Journal of Agricultural Economics, 85(2), 372-386.

Nayab, D., \& Arif, G. M. (2014). Pakistan Panel Household Survey: Sample size and attrition. Pakistan Development Review, 53(2), 223-237.

Reardon, T., Berdegué, J., \& Escobar, G. (2001). Rural nonfarm employment and incomes in Latin America: Overview and policy implications. World Development, 29(3), 395-409.

van der Ploeg, J. D. (2014). Peasant-driven agricultural growth and food sovereignty. Journal of Peasant Studies, 41(6), 999-1030.

Wiggins, S., Kirsten, J., \& Llambí, L. (2010). The future of small farms. World Development, 38(10), 1341-1348. 


\section{Appendix}

Table A1: Occupations in households with three sources of income

\begin{tabular}{lccccc}
\hline $\mathbf{2 0 0 1}$ & $\begin{array}{c}\text { Livestock, } \\
\text { wages, land }\end{array}$ & $\begin{array}{c}\text { Livestock, } \\
\text { cultivation, } \\
\text { land }\end{array}$ & $\begin{array}{c}\text { Cultivation, } \\
\text { wages, land }\end{array}$ & $\begin{array}{c}\text { Livestock, } \\
\text { enterprise, } \\
\text { wages }\end{array}$ & $\begin{array}{c}\text { Livestock, } \\
\text { wages, } \\
\text { cultivation }\end{array}$ \\
\hline $\begin{array}{l}\text { Livestock, } \\
\text { wages, land }\end{array}$ & 7 & 2 & 2 & 2 & 2 \\
$\begin{array}{l}\text { Livestock, } \\
\text { cultivation, } \\
\text { land }\end{array}$ & 15 & 138 & 11 & 4 & 22 \\
$\begin{array}{l}\text { Cultivation, } \\
\text { wages, land }\end{array}$ & 1 & 3 & 7 & 0 & 6 \\
$\begin{array}{l}\text { Livestock, } \\
\text { enterprise, }\end{array}$ & 0 & 0 & 1 & 4 & 1 \\
$\begin{array}{l}\text { wages } \\
\begin{array}{l}\text { Livestock, } \\
\text { wages, } \\
\text { cultivation }\end{array}\end{array}$ & 0 & 0 & 0 & 0 & 0 \\
\hline
\end{tabular}

Source: Authors' calculations based on data from the PPHS 2010.

\section{Table A2: Occupations in households with four sources of income}

\begin{tabular}{lccccc}
\hline $\mathbf{2 0 0 1}$ & $\begin{array}{c}\text { Cultivation, } \\
\text { wages, land, } \\
\text { livestock }\end{array}$ & $\begin{array}{c}\text { Land, } \\
\text { enterprise, } \\
\text { livestock, } \\
\text { wages }\end{array}$ & $\begin{array}{c}\text { Cultivation, } \\
\text { wages, } \\
\text { livestock, } \\
\text { enterprise }\end{array}$ & $\begin{array}{c}\text { Cultivation, } \\
\text { enterprise, } \\
\text { land, wages }\end{array}$ & $\begin{array}{c}\text { Land, } \\
\text { cultivation, } \\
\text { livestock, } \\
\text { enterprise }\end{array}$ \\
\hline $\begin{array}{l}\text { Cultivation, } \\
\text { wages, land, } \\
\text { livestock }\end{array}$ & 116 & 4 & 1 & 3 & 16 \\
$\begin{array}{l}\text { Land, } \\
\text { enterprise, }\end{array}$ & 1 & 0 & 0 & 1 & 0 \\
$\begin{array}{l}\text { livestock, } \\
\text { wages }\end{array}$ & 0 & 0 & 0 & 0 & 0 \\
$\begin{array}{l}\text { Cultivation, } \\
\text { wages, } \\
\text { livestock, } \\
\text { enterprise }\end{array}$ & 0 & & & & 0 \\
$\begin{array}{l}\text { Cultivation, } \\
\text { enterprise, } \\
\text { land, wages }\end{array}$ & 0 & 0 & 1 & & 0 \\
$\begin{array}{l}\text { Land, } \\
\text { cultivation, } \\
\text { livestock, } \\
\text { enterprise }\end{array}$ & 1 & & & & \\
\hline
\end{tabular}

Source: Authors' calculations based on data from the PPHS 2010. 
Table A3: Households moving from three to four sources of income

\begin{tabular}{lcccccc}
\hline $\mathbf{2 0 0 1}$ & $\begin{array}{c}\text { Land, } \\
\text { cultivation, } \\
\text { wages }\end{array}$ & $\begin{array}{c}\text { Land, } \\
\text { cultivation, } \\
\text { livestock }\end{array}$ & $\begin{array}{c}\text { Livestock, } \\
\text { wages, } \\
\text { cultivation }\end{array}$ & $\begin{array}{c}\text { Wages, } \\
\text { land, } \\
\text { livestock }\end{array}$ & $\begin{array}{c}\text { Enterprise, } \\
\text { wages, } \\
\text { livestock }\end{array}$ & Others \\
\hline $\begin{array}{l}\text { Land, } \\
\text { livestock, } \\
\text { cultivation, } \\
\text { wages }\end{array}$ & 31 & 46 & 37 & 19 & 3 & 13 \\
$\begin{array}{l}\text { Land, } \\
\text { livestock, }\end{array}$ & 1 & 1 & 0 & 0 & 0 & 0 \\
$\begin{array}{l}\text { wages, } \\
\text { enterprise }\end{array}$ & 0 & 0 & 0 & 0 & 0 & 0 \\
$\begin{array}{l}\text { Cultivation, } \\
\text { wages, } \\
\text { livestock, } \\
\text { enterprise }\end{array}$ & 0 & & & & & 3 \\
$\begin{array}{l}\text { Cultivation, } \\
\text { enterprise, } \\
\text { land, wages }\end{array}$ & 0 & 0 & 0 & 0 & 0 & 3 \\
$\begin{array}{l}\text { Land, } \\
\text { cultivation, } \\
\text { livestock, } \\
\text { enterprise }\end{array}$ & 1 & 6 & 3 & 0 & 1 & \\
\hline
\end{tabular}

Source: Authors' calculations based on data from the PPHS 2010.

Table A4: Households moving from three to two sources of income

\begin{tabular}{lccccc}
\hline $\mathbf{2 0 0 1}$ & $\begin{array}{c}\text { Land, } \\
\text { cultivation, } \\
\text { wages }\end{array}$ & $\begin{array}{c}\text { Land, } \\
\text { cultivation, } \\
\text { livestock }\end{array}$ & $\begin{array}{c}\text { Livestock, } \\
\text { wages, } \\
\text { cultivation }\end{array}$ & $\begin{array}{c}\text { Wages, land, } \\
\text { livestock }\end{array}$ & $\begin{array}{c}\text { Enterprise, } \\
\text { wages, } \\
\text { livestock }\end{array}$ \\
\hline $\begin{array}{l}\text { Cultivation, } \\
\text { wages }\end{array}$ & 7 & 18 & 10 & 4 & 3 \\
$\begin{array}{l}\text { Cultivation, } \\
\text { livestock }\end{array}$ & 0 & 0 & 0 & 0 & 0 \\
$\begin{array}{l}\text { Livestock, } \\
\text { wages }\end{array}$ & 8 & 16 & 28 & 34 & 16 \\
$\begin{array}{l}\text { Livestock, } \\
\text { land }\end{array}$ & 0 & 3 & 0 & 2 & 0 \\
$\begin{array}{l}\text { Livestock, } \\
\text { enterprise }\end{array}$ & 0 & 0 & 0 & 1 & 5 \\
$\begin{array}{l}\text { Enterprise, } \\
\text { wages }\end{array}$ & 1 & 0 & 0 & 1 & 2 \\
Land, wages & 1 & 3 & 0 & 7 & 0 \\
\hline
\end{tabular}

Source: Authors' calculations based on data from the PPHS 2010. 